\title{
BMP4 and PHLDA1 are plausible drug-targetable candidate genes for KRAS G12A-, G12D-, and G12V-driven colorectal cancer
}

\author{
Shumpei Ohnami ${ }^{1}$ (I) $\cdot$ Kouji Maruyama ${ }^{2} \cdot K^{2}$ Kai Chen $^{3} \cdot$ Yu Takahashi $^{2} \cdot$ Keiichi Hatakeyama $^{4} \cdot$ Keiichi Ohshima $^{4}$. \\ Yuji Shimoda ${ }^{1,5} \cdot$ Ai Sakai $^{1,5}$ - Fukumi Kamada ${ }^{1}$. Sou Nakatani ${ }^{1}$. Akane Naruoka ${ }^{6}$ Sumiko Ohnami ${ }^{1}$. \\ Masatoshi Kusuhara ${ }^{8}$. Yasuto Akiyama ${ }^{7}$. Hiroyasu Kagawa ${ }^{3} \cdot$ Akio Shiomi $^{3} \cdot$ Takeshi Nagashima $^{1,5}$. \\ Kenichi Urakami ${ }^{1} \cdot$ Ken Yamaguchi $^{9}$
}

Received: 14 September 2020 / Accepted: 28 April 2021 / Published online: 12 May 2021

(c) The Author(s) 2021

\begin{abstract}
Despite the frequent detection of KRAS driver mutations in patients with colorectal cancer (CRC), no effective treatments that target mutant KRAS proteins have been introduced into clinical practice. In this study, we identified potential effector molecules, based on differences in gene expression between CRC patients carrying wild-type $K R A S(n=390)$ and those carrying $K R A S$ mutations in codon $12(n=240)$. CRC patients with wild-type KRAS harboring mutations in $H R A S, N R A S, P I K 3 C A$, $P I K 3 C D, P I K 3 C G, R A L G D S, B R A F$, or $A R A F$ were excluded from the analysis. At least 11 promising candidate molecules showed greater than two-fold change between the KRAS G12 mutant and wild-type and had a Benjamini-Hochberg-adjusted $P$ value of less than 1E-08, evidence of significantly differential expression between these two groups. Among these 11 genes examined in cell lines transfected with KRAS G12 mutants, BMP4, PHLDA1, and GJB5 showed significantly higher expression level in KRAS G12A, G12D, and G12V transfected cells than in the wild-type transfected cells. We expect that this study will lead to the development of novel treatments that target signaling molecules functioning with KRAS G12-driven CRC.
\end{abstract}

Keywords BMP4 $\cdot$ PHLDA1 - Colorectal cancer $\cdot$ KRAS mutation · Therapeutic targets

Shumpei Ohnami

s.onami@scchr.jp

1 Cancer Diagnostics Research Division, Shizuoka Cancer Center Research Institute, 1007 Shimonagakubo, Nagaizumi-cho, Sunto-gun, Shizuoka 411-8777, Japan

2 Experimental Animal Facility, Shizuoka Cancer Center Research Institute, Shizuoka, Japan

3 Division of Colon and Rectal Surgery, Shizuoka Cancer Center Hospital, Shizuoka, Japan

4 Medical Genetics Division, Shizuoka Cancer Center Research Institute, Shizuoka, Japan

5 SRL Inc, Tokyo, Japan

6 Drug Discovery and Development Division, Shizuoka Cancer Center Research Institute, Shizuoka, Japan

7 Immunotherapy Division, Shizuoka Cancer Center Research Institute, Shizuoka, Japan

8 Shizuoka Cancer Center Research Institute, Shizuoka, Japan

9 Shizuoka Cancer Center, Shizuoka, Japan

\section{Introduction}

The incidence and mortality rates of colorectal cancer (CRC) have recently been increasing in Japan [1]. Surgical resections can cure CRC in the early stage, and advances in pharmacotherapy have also improved the treatment outcomes in patients with unresectable and advanced/recurrent-stage CRC. However, the five-year survival rate in patients with advanced stage IV CRC is quite low at approximately $18 \%$ [2]. Therefore, new therapeutic drugs, particularly molecular targeted agents with fewer adverse drug reactions, need to be developed for improving the prognosis in CRC patients [3]. Advanced CRC is typically treated with monoclonal antibodies targeting epidermal growth factor receptor (EGFR), such as cetuximab or panitumumab, used alone or in combination with standard chemotherapy, but CRC patients harboring KRAS mutations do not respond to the antibodybased anti-EGFR treatment [4].

RAS proteins, including KRAS as one of the molecules that play a central role in intracellular signaling pathways, appear to be involved in a wide range of processes including 
cell proliferation, differentiation, metabolism, and cell death [5-7]. Therefore, drugs that directly target RAS proteins that are ubiquitously expressed as house-keeping genes are more likely to have unanticipated reactions with other proteins in the body [8]. Wild-type KRAS has been shown to act as a tumor suppressor gene during the differentiation of myeloid cells [9] and inhibit lung carcinogenesis in murine teratomas [10]. Literature surveys suggest that the wild-type KRAS could play an onco-suppressor role [11-13]. KRAS mutations are observed in approximately $40 \%$ of patients with CRC and occur frequently in codon 12 or 13 and less frequently in codons 146 or 61 . A study focusing on immortalized human bronchial epithelial cells reported differences in the degree of constitutive activation of the KRAS protein, rates of increase in tumor cell proliferation, and the degree of activation of proliferative signals downstream of KRAS, depending on the mutation sites in the KRAS gene [14]. In addition, downstream effector molecules of KRAS signaling pathways were shown to differ according to tumor type [15]. These observations raised the possibility that the mechanism by which activated KRAS binds preferentially to its downstream partners' genes, and how these interactions after cell determination, may differ among humans.

KRAS mutations are considered to occur during initiation or early event in colorectal carcinogenesis $[16,17]$, but not in the malignant progression of CRC because it has been found in dysplastic lesions and adenomatous polyps, and such mutations alone are insufficient for the sustained growth of cancer. Once the KRAS mutations occur, the KRAS activation signaling will be sustained for over 10 years in the somatic evolution of adult cancers. More specifically, the presence of KRAS mutations alone is considered to be insufficient for malignant transformations unless they function in cooperation with a particular set of other cancer-related genes in vivo. If this is true, identification of signaling molecules functioning in cooperation with KRAS may allow for the development of a new strategy for suppressing cancer without the use of KRAS inhibitors. MEK inhibitors are being evaluated for their clinical efficacy in targeting CRC with KRAS mutations and have a greater dependence on MAPK pathway signaling [18]; however, it seems that MAPK pathway inhibition during the treatment of CRC with KRAS mutation remains elusive [6, 19, 20]. Furthermore, studies have shown that MEK inhibitors did not improve overall survival in patients with advanced non-small cell lung cancer (NSCLC) [21] or pancreatic cancer [22] harboring KRAS mutations. An effective combination therapy using TBK1 and MEK or BET inhibitors has also been reported in aggressive murine KRAS-driven lung cancer [23]. In addition to MEK inhibitors, a recent study revealed that a covalent KRAS inhibitor could inhibit tumor cell growth in NSCLC with KRAS G12C mutation [24, 25], but not in CRC [26].
Although many KRAS-associated molecules play an important role in regulating KRAS transcription [27], the regulatory mechanisms underlying its activation in vivo have not been fully elucidated. In this study, we first comprehensively analyzed the mutations and expressions of known genes involved in the KRAS signaling pathway in patients with CRC. The KRAS G12 mutation is found at a characteristically high frequency and is associated with worse overall survival in patients with CRC [28]. Therefore, next, we explored the potential effector molecules whose gene expression levels differed between CRC patients with wild-type KRAS and those with a KRAS mutation in codon 12 . We then validated these candidate genes by transfecting KRAS mutants into human cells. Effective therapies targeting KRAS signaling pathway have not yet been introduced in clinical practice. Moreover, RAS proteins have been dismissed as undruggable targets for many years $(5,6)$. We hope that this study paves the way for the development of novel treatments that target signaling molecules functioning in the KRAS G12-driven CRC.

\section{Materials and methods}

\section{Subjects}

We performed the Whole Exome Sequencing (WES) and Comprehensive Cancer Panel (CCP) using blood samples and fresh surgical specimens. We then conducted Gene Expression Profiling (GEP) using matched tumor and adjacent normal tissues from each patient. Tumor-specific single nucleotide variants (SNVs) were determined by comparing tumor tissue with blood cell data from the same patient. Between January 2014 and January 2017, the samples were obtained from 906 patients with CRC treated with surgery at the Shizuoka Cancer Center Hospital, Shizuoka, Japan (Table 1).

WES/CCP and GEP were performed using the Ion Proton system and Agilent system, respectively. Details of the experimental procedures have been described in previous reports [29-32].

\section{Ethical statement}

All experimental protocols were approved by the Institutional Review Board at the Shizuoka Cancer Center (Authorization Number: 25-33). Written informed consent was obtained from all patients for the participation in this study. All experiments using clinical samples were carried out in accordance with the approved guidelines [33]. 
Table 1 Characteristics of the colorectal cancer patients

\begin{tabular}{|c|c|c|c|}
\hline & $\begin{array}{l}\text { KRAS } \\
\text { wild- } \\
\text { type }\end{array}$ & $K R A S$ mutated & ${ }^{\text {a }} P$ value \\
\hline Total number & 534 & 372 & \\
\hline \multicolumn{4}{|l|}{ Tumor type } \\
\hline Colon & 302 & 194 & \\
\hline Rectum & 232 & 178 & 0.20 \\
\hline \multicolumn{4}{|l|}{ Location of the primary tumor } \\
\hline Anal & 3 & 1 & \\
\hline Ascending & 69 & 76 & \\
\hline Cecum & 18 & 37 & \\
\hline Descending & 21 & 8 & \\
\hline Sigmoid & 132 & 57 & \\
\hline Transverse & 59 & 15 & \\
\hline Rectum & 232 & 178 & \\
\hline \multicolumn{4}{|l|}{ Clinical stage } \\
\hline Stage I & 39 & 52 & \\
\hline Stage II & 123 & 89 & \\
\hline Stage III & 303 & 187 & \\
\hline Stage IV & 63 & 42 & \\
\hline Unknown & 6 & 2 & \\
\hline \multicolumn{4}{|l|}{ Age, y } \\
\hline$<45$ & 39 & 13 & \\
\hline $46-55$ & 58 & 24 & \\
\hline $56-65$ & 128 & 56 & \\
\hline$\geq 66$ & 309 & 85 & \\
\hline \multicolumn{4}{|l|}{ Gender } \\
\hline Male & 337 & 194 & \\
\hline Female & 197 & 178 & 0.001 \\
\hline \multicolumn{4}{|l|}{ Smoking status } \\
\hline Nonsmokers & 188 & 165 & \\
\hline Smokers & 346 & 207 & 0.006 \\
\hline Unknown & 0 & 0 & \\
\hline \multicolumn{4}{|l|}{ Pack-years ${ }^{\mathrm{b}}$} \\
\hline 0 & 188 & 165 & \\
\hline Light smokers $(>0$ to $<20)$ & 90 & 69 & \\
\hline Heavy smokers $(\geq 20)$ & 237 & 129 & 0.079 \\
\hline $\begin{array}{l}\text { Smokers but pack-years } \\
\text { unknown }\end{array}$ & 19 & 9 & \\
\hline Unknown & 0 & 0 & \\
\hline \multicolumn{4}{|l|}{ Drinking status } \\
\hline Nondrinkers & 118 & 98 & \\
\hline Drinkers & 334 & 209 & 0.09 \\
\hline Unknown & 82 & 65 & \\
\hline
\end{tabular}

${ }^{\text {a }} P$ value by Fisher exact test

${ }^{b}$ Pack-years defined as number of packs of cigarettes smoked per day times of years of smoking

\section{Cell lines}

The human 293 embryonic kidney cell line and human CRC cell line, Caco-2, were obtained from the American Type Culture Collection (ATCC; Manassas, VA, USA) and cultured in Dulbecco's modified Eagle's medium supplemented with $10 \%$ fetal bovine serum at $37^{\circ} \mathrm{C}$ in $5 \% \mathrm{CO}_{2}$. Both 293 and Caco-2 cells have wild-type $K R A S$ as well as $B R A F$ and $P I K 3 C A$, which are direct downstream effectors of RAS signaling.

\section{Construction of KRAS expression vector}

To construct the KRAS cDNA expression vectors to transduce the entire KRAS coding exons representing either the mutant or wild-type forms, the respective cDNA was synthesized using a $1 \mu \mathrm{g}$ of total RNA isolated from normal breast tissue. The cDNA was amplified using the primers for the KRAS sequence including a Kozak translation initiation sequence containing an ATG initiation codon for proper initiation of translation. The polymerase chain reaction $(\mathrm{PCR})$ products were cloned into the pcDNA3.1 D/ V5-His vector (Thermo Fisher Scientific) downstream to the human cytomegalovirus promoter to express the KRAS protein fused with a V5-epitope tag at its C-terminus. Sitedirected mutagenesis was performed according to the manufacturer's protocol (In-Fusion HD Cloning Kit, TaKaRa, Japan). The resulting pcDNA3.1D/V5-His/KRAS vectors were designated as pKRAS-WT, pKRAS-A, pKRAS-C, pKRAS-D, pKRAS-R, pKRAS-S, and pKRAS-V, and they harbored wild-type, G12A, G12C, G12D, G12R, G12S, and G12V mutants at codon 12 of the KRAS cDNA, respectively. A pcDNA3.1 D/V5-His/LacZ (named $p L a c Z$ ) served as a negative control.

\section{Transfection of KRAS expression vectors into cells}

The 293 cells had a high transfection efficiency ( $90 \%$ or more), and the Caco-2 cells were transfected using TransIT-293 transfection reagent (Mirus Bio LLC, Madison) or Lipofectamine 3000 (Invitrogen) and Opti-MEM, as previously described [34]. The cells were seeded at $3-5 \times 10^{5}$ cells/well in 6-well plates; $24-48 \mathrm{~h}$ later, when the cells reached $70-80 \%$ confluence, they were transfected with pKRAS-WT, pKRAS-A, pKRAS-C, pKRAS-D, pKRAS$\mathrm{R}$, pKRAS-S, pKRAS-V, or pLacZ expression vector. After 4-5 h, the medium was replaced with DMEM, and the cells were incubated for 24 or $48 \mathrm{~h}$.

\section{Western blot analyses of transfected cells}

Western blot analyses of the cells transfected with either of the vectors indicated above were performed essentially as 
described [34]. The protein samples were size fractionated using a gradient $12 \%$ SDS polyacrylamide gel, and a commercially available antibodies were used for the detection of the V5 peptide tag (Thermo Fisher Scientific) and $\beta$-actin protein (Sigma Chemical Co, St. Louis, MO).

\section{Validation of candidate genes using real-time quantitative RT-PCR analysis}

A total RNA from cells transfected with pKRAS expression vectors as described above was isolated using Isogen reagent (Nippon Gene, Japan), and the cDNA was synthesized. The cDNA was subjected to the real-time quantitative RT-PCR (qPCR) using the Universal Master Mix according to the manufacturer's specifications. Primers and TaqMan probes for candidate genes were used along with commercially available online (Thermo Fisher Scientific). The qPCR signal obtained with the optimal cycling parameters for each gene was normalized to $\beta$-actin.

\section{Statistical analysis}

A significant difference in gene expression between the $K R A S$ wild-type and KRAS-mutated CRC was calculated using Welch's t-test, and the significance level was set to $1 \mathrm{E}-08$ by Benjamini-Hochberg (BH) correction for multiple testing. In the comparative analysis of candidate genes, Welch's $t$ test was applied to compare gene expression levels among the vector-transfected cells. Fisher's exact test was used to compare the subjects between the groups.

\section{Results}

\section{Whole exome sequencing and deep sequencing of the custom cancer panel in CRC}

We used WES to analyse 1074 cancer-related genes from 27 databases [29] in paired tumor tissue and blood samples to detect genetic changes in CRC. Simultaneously, we used the CCP comprising 409 target genes to conduct deep sequencing of tumor tissue samples to validate the WES data. The mean depth of coverage of the target regions was 115-fold for WES and 1027-fold for CCP. KRAS mutations were detected in $41.0 \%$ of all cases (372/906), which was consistent with the frequencies for these mutations observed in previous studies [35]. The concordance rate between the WES and CCP for KRAS mutations was $91.4 \%$ (340/372). The non-coincident was composed of WES-negative (15/372) and CCP-negative (17/372) for KRAS mutations.

Among KRAS-mutated CRC samples, the frequencies KRAS mutations were as follows: G12, 64.5\% (240/372); G13, 20.2\% (75/372); A146, 8.1\% (30/372); Q61, 2.7\%
(10/372); K117, 2.7\% (10/372); Q22, 0.5\% (2/372); A59, $0.5 \%(2 / 372)$, and $0.3 \%$ (1/372) for A14, G77 and Y64 mutations. Within the KRAS G12 mutations, the frequencies of the various types of substitutions were $47.9 \%$ for $K R A S$ G12D (115/240), 26.3\% for G12V (63/240), 9.2\% for G12A (22/240), 8.8\% for G12C (21/240), 5.8\% for G12S (14/240), and $2.1 \%$ for G12R $(5 / 240)$.

In KRAS mutated CRC samples, somatic mutations in PIK3CA (86/372, 23.1\%) were the most frequently detected among the genes known to mediate RAS-associated responses. On the other hand, somatic mutations in $B R A F$ (61/534, 11.4\%), PIK3CG (27/534, 5.1\%), PIK3CD (16/534, $3.0 \%)$, and $N R A S(22 / 534,4.1 \%)$ were frequently detected in KRAS wild-type CRC compared to KRAS-mutated CRC. The median tumor mutational burden (TMB) in KRAS wildtype CRC $(n=534)$ and KRAS mutated CRC $(n=372)$ were 8.27 mutations $/ \mathrm{Mb}$, and 13.27 mutations/Mb, respectively. Notably, somatic mutations in $R A L G D S$ were detected in $K R A S$ wild-type CRC, but not in KRAS mutated CRC. It is intriguing that our WES analysis revealed that the RASassociated genes were frequently mutated at high levels in patients with KRAS wild-type CRC compared to KRASmutated CRC (Fig. 1).

\section{Comprehensive gene expression analysis of KRAS pathway-associated genes using DNA microarray}

Of the known downstream genes in the KRAS pathway, increased expression was observed for CCND1, DUSP2, DUSP4, ETS2, JUN, RAC2, RAC3, SPRY4, ELK1, RAL$G D S$, and RASAL1 in KRAS mutated CRC (Fig. 2). Conversely, the expression levels of CCND1, DUSP2, ETS2, $J U N$, and RALGDS were decreased in lung and pancreatic adenocarcinomas with KRAS mutations (Fig. 3). The signaling cascades downstream of the KRAS protein leading to the following pathways involving RAF/MAPK/ERK, PI3K/ AKT, and RAL GDS/RAL have been well elucidated and are considered to differ according to the tumor type. It is noteworthy that transcription factors, such as ETS2, JUN, and $E L K 1$, were upregulated in the KRAS mutated CRC, but not in lung and pancreatic cancers. Thus, the genes corresponding to these transcription factors may be promising targets for treating KRAS mutated CRC. However, the differences in expression levels of ETS2, JUN, and ELK1 between the $K R A S$ mutant and the wild-type were not statistically significant (BH-adjusted $P$ value, $>0.26$ ).

\section{Exploring of the drug-targetable oncogenes functioning with the KRAS-G12 mutant}

To exploit the novel KRAS G12 mutant targets, GEP was assessed in KRAS G12 mutated CRC $(n=240)$ and KRAS 


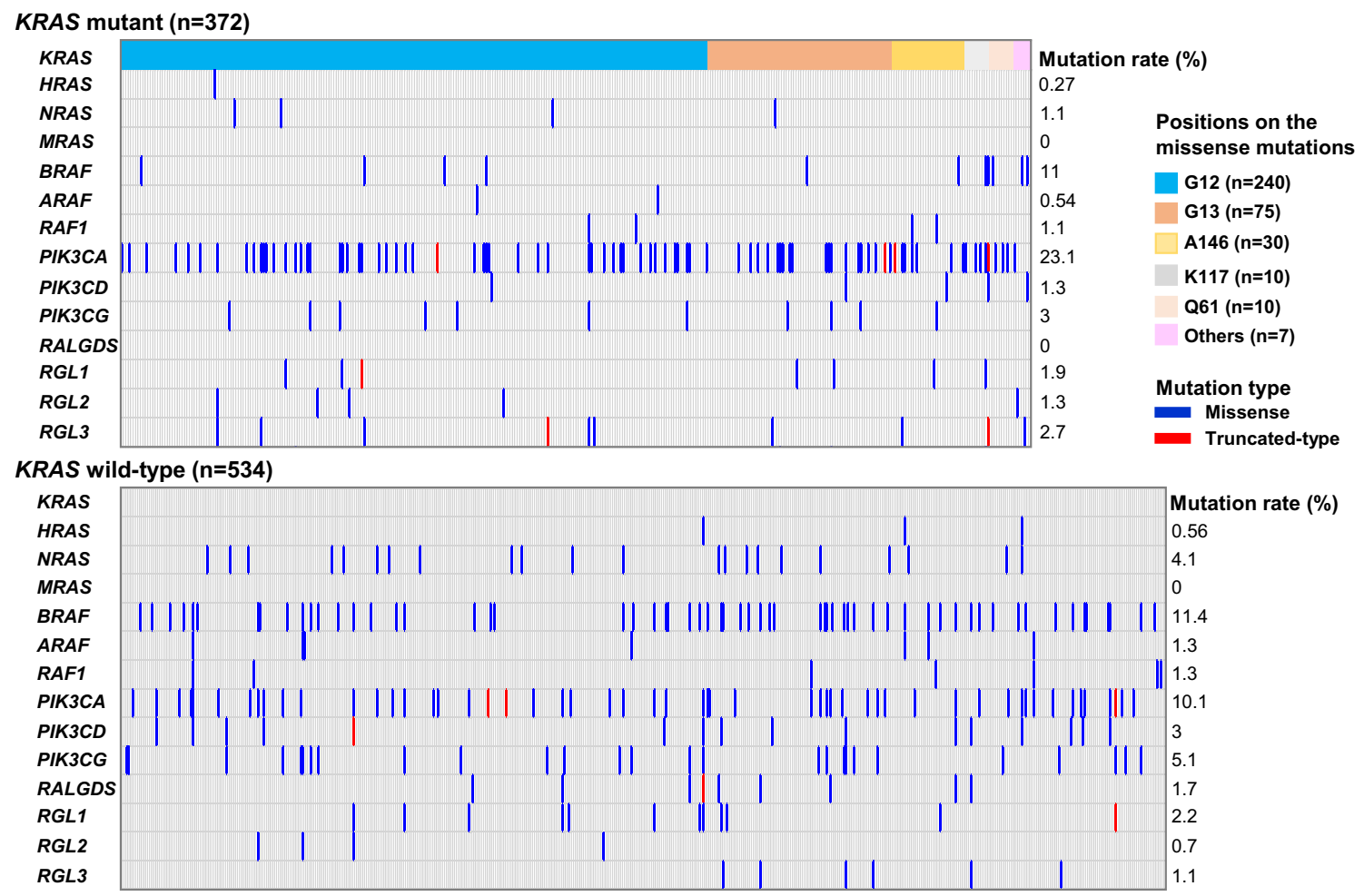

Fig. 1 Genomic alterations in the $K R A S$-related genes in CRC. $R A S$ related genes were obtained from the NCI RAS Initiative [6]: a Mutation frequencies of genes that directly regulate RAS proteins in 906 colorectal cancer patients with $(n=372)$ or without $(n=534) K R A S$ mutations. Each column denotes an individual tumor. Left: percentage of samples with mutations in a given gene. Others (Pink Square) in the positions on KRAS mutations indicated Q22 $(n=2)$, A59 $(n=2), \mathrm{A} 14(n=1), \mathrm{G} 77(n=1)$, and Y64 $(n=1)$ wild-type $(n=390)$. KRAS wild-type CRC harboring mutations in HRAS, NRAS, PIK3CA, PIK3CD, PIK3CG, $R A L G D S, R G L 1-3, B R A F, A R A F$, or RAFl were excluded from the analysis because mutations in these genes directly affect $K R A S$-mediated signaling. The difference in the normalized signal intensities (fold change, FC) between the tumor and adjacent normal tissues was then calculated. The KRAS G12 mutated CRC $(n=240)$ and the selected $K R A S$ wild-type CRC $(n=390)$ harbored $A P C$ mutation at $79.6 \%$ (191/240) and 74.9\% (292/390), respectively; however, this difference that was not statistically significant $(P=0.21)$. On the other hand, the incidence of TP53 mutations showed a statistically significant difference $(P<0.01)$ between KRAS G12 mutated CRC $(64.5 \%, 143 / 240)$ and $K R A S$ wild-type CRC $(83.1 \%, 324 / 390)$. There were number 13,222 genes that showed a positive FC value (mutant/ wild-type) in KRAS G12 mutated CRC compared to the $K R A S$ wild-type CRC. It was also noted that at least 11 promising candidate molecules showed greater than twoFC between KRAS G12 mutant and wild-type and had a BH-adjusted $P$ value of less than $1 \mathrm{E}-08$ and showed significant differential expression between these two groups (Table 2).

\section{Validation of promising candidate genes in KRAS-mediated signaling}

To verify the expression levels of the candidate genes in KRAS G12 mutated CRC, expression plasmids of KRAS variants, designated pKRAS-WT (wild-type), pKRAS-A (G12A), pKRAS-C (G12C), pKRAS-D (G12D), pKRAS-R (G12R), pKRAS-S (G12S), pKRAS-V (G12V), and pLacZ (control vector), were transfected into the human 293 embryonic kidney cells harboring KRAS wild-type. The level of gene expression in the transfected cells was analyzed using qPCR. The expression levels of the 11 candidate genes varied depending on the type of KRAS mutant, but the expression was effectively induced in G12A, G12D, and G12V mutants. Remarkably, as shown in Fig. 4, BMP4, PHLDA1, and $G J B 5$ expression levels were significantly upregulated in the G12A-, G12D-, G12V- transfected cells, compared those in the WT-transfected cells, suggesting that these genes can be added to the list of candidates of KRAS G12A, G12D, or G12V target genes in CRC. To re-verify the expression data of BMP4, PHLDA1, and GJB5 were validated in the KRAS mutants-transfected 293 cells, and real-time RT-PCR analysis was performed for the KRAS mutant transfected Caco-2 $\mathrm{CRC}$ cells. Although the measured gene expression level 


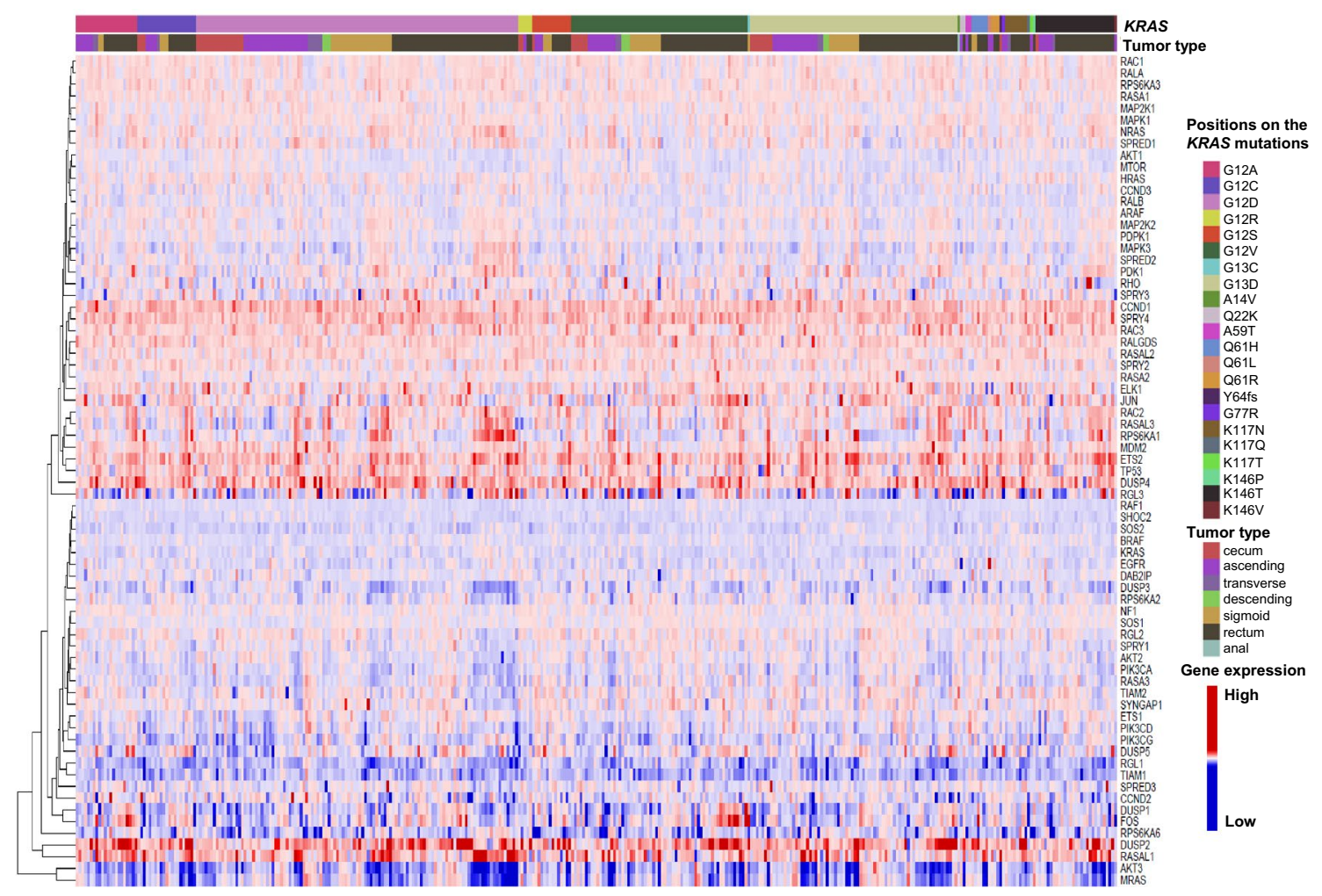

Fig. 2 A clustered heat map showing 65 of the $K R A S$ pathway-associated genes that are differentially expressed in tumor tissues relative to adjacent normal tissues in $374 \mathrm{CRC}$ with $K R A S$ mutations. The tumor type in CRC indicates the location of the primary tumor (right upper panel). The expression levels $\left(\log _{2}\right)$ are normalized for each gene and shown by the graded color scale was different between the 293 and Caco- 2 cells, the effect of KRAS mutant transduction, that is, G12D, G12A, and G12V, was confirmed in Caco-2 cells (Fig. 5). This inconsistency in induced gene expression between the 293 and Caco-2 cells may be attributed to differences in transfection efficiency, susceptibility, and cellular differentiation, the nature of which should be explored further. The up-regulation of these genes was re-verified in an independent experiment (data not shown). BMP4, PHLDAl, and GJB expression levels in pairs of tumors and adjacent normal tissues from the patients with CRC obtained using GEP were significantly higher $(P<0.001)$ in the KRAS G12 mutant compared with those in the wild-type (Fig. 6a). The KRAS G12D and G12V mutants also showed increased expression levels $(P<0.001)$ in comparison with the wild-type (Fig. 6b) Western blot analysis using the V5-tagged antibody showed no difference in the KRAS protein levels between the pKRAS-WT and pKRAS mutated cells. The entire transfection experiment was repeated twice, showing the same KRAS protein level in the transfected cells. The other eight genes (genes shown in Table 2) were not verified by qPCR (Fig. 7). In addition to the 11 candidate genes, we analyzed the TLR4, RHOBTB3, MFHAS1, S100A6, S100A11, and DUSP4 genes that had a BH-adjusted $P$ value of less than $1 \mathrm{E}-09$ between KRAS G12 mutant and wild-type, but less than two-fold, which have been implicated in the oncogenic functions (Supplementary Table). None of these genes showed a significantly different expression levels in KRAS G12 mutant transfected cells from those in the wild-type or LacZ transfected control cells. (Fig. 8).

\section{Discussion}

In this study, we identified BMP4, PHLDA1, and GJB5 as the most likely genes that are activated downstream of the KRAS G12-driver mutation in CRC, especially the G12A, G12D, and G12V mutations. On the other hand, transfection of the G12C, G12R, and G12S mutants showed lower expression of BMP4, PHLDA1, and GJB5, but higher than those of the wild-type, compared with the G12A, G12D, and G12V mutants. Presently, the detailed mechanism for these differential expression profiles is not clear; however, specific KRAS mutations have unique biological and clinical behaviors. Hunter et al. [36] have systemically examined the biochemical and biophysical properties of common KRAS mutants and showed that a cell line harboring the G12A mutation, which had high affinity for 

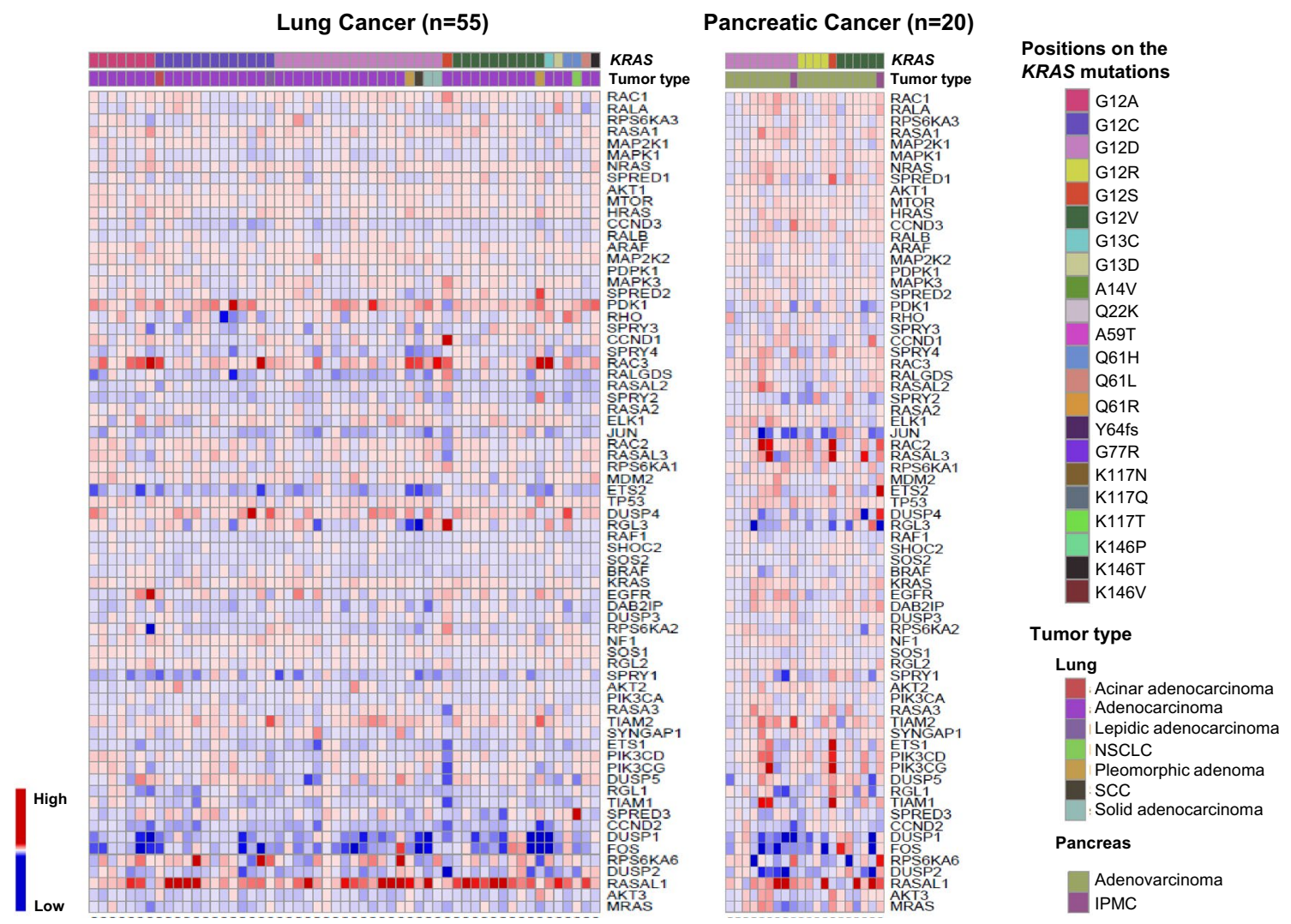

Fig. 3 Heat map showing 65 of the KRAS pathway-associated genes that are differentially expressed in tumor tissues compared to adjacent normal tissues in 55 lung and 20 pancreatic cancers with KRAS mutations. The order of the KRAS-related genes is the same as in CRC samples (Fig. 2). Samples for lung (left) and pancreatic (right) cancers with KRAS mutations were obtained from our previous study [29]

Table 2 List of promising candidate genes that showed significant differences between KRAS G12 mutated and wild-type CRC

\begin{tabular}{lllccc}
\hline & Gene & Description & FC $_{\mathrm{a}}$ & \multicolumn{2}{c}{$P$-value } \\
\cline { 3 - 5 } & & & Welch's t test & BH-adjusted \\
\hline 1 & HOXB6 & Homeobox B6 & 2.72 & $3.42 \mathrm{E}-16$ & $4.50 \mathrm{E}-13$ \\
2 & PHLDA1 & Pleckstrin homology like domain family A member 1 & 3.26 & $6.02 \mathrm{E}-15$ & $3.79 \mathrm{E}-12$ \\
3 & BMP4 & Bone morphogenetic Protein 4 & 2.05 & $1.22 \mathrm{E}-14$ & $6.83 \mathrm{E}-12$ \\
4 & OTUB2 & OTU deubiquitinase, ubiquitin aldehydebinding 2 & 2.81 & $1.99 \mathrm{E}-14$ & $1.05 \mathrm{E}-11$ \\
5 & TGFBI & Transforming growth factor beta 1 & 2.43 & $2.92 \mathrm{E}-14$ & $1.36 \mathrm{E}-11$ \\
6 & SLC28A3 & Solute carrier family 28 member 3 & 6.78 & $6.76 \mathrm{E}-13$ & $1.94 \mathrm{E}-10$ \\
7 & TMEM211 & Transmembrane protein 211 & 9.95 & $7.89 \mathrm{E}-12$ & $1.42 \mathrm{E}-09$ \\
8 & DNAH2 & Dynein axonemal heavy chain 2 & 4.30 & $1.33 \mathrm{E}-11$ & $2.27 \mathrm{E}-09$ \\
9 & FAM169A & Family with sequence similarity 169 member A & 3.36 & $2.15 \mathrm{E}-11$ & $3.31 \mathrm{E}-09$ \\
10 & GJB5 & Gap junction protein beta 5 & 14.06 & $2.29 \mathrm{E}-11$ & $3.46 \mathrm{E}-09$ \\
11 & C2orf70 (FAM166C) & Family with sequence similarity 166 member C & 2.66 & $2.39 \mathrm{E}-11$ \\
\hline
\end{tabular}

${ }^{\mathrm{a}} F C$ (Fold Change) in the normalized signal intensities between KRAS G12 mutated CRC and KRAS wild-type CRC

RAF kinase and low intrinsic GTPase activity, showed the highest sensitivity to MEK inhibitor, suggesting that G12A mutation intensely affects the downstream signal of KRAS. In our present study, the highest induction was caused by
G12A mutant in several genes (Figs.4 and 5). Additionally, the G12D mutation, which is predicted to be a low RAF activator, is associated with PI3K, but not RAF kinase and does not induce ERK phosphorylation in NIH3T3 cells. 
Fig. 4 Promising candidate genes are validated using qPCR in the KRAS G12 mutant transfected 293 cells: a Relative expression ratio is defined as the ratio between the expression level of a gene to that of the internal reference gene, $\beta$-actin. White and black columns indicate the expression levels at 24 and $48 \mathrm{~h}$ after transfection, respectively. The assays are carried out in triplicates and means \pm standard deviation are plotted, b KRAS protein expression in the 293 cells transfected with KRAS mutants, wild-type, or LacZ control vector analyzed using Western blot with V5 and $\beta$-actin antibodies. The $\beta$-actin is used as a loading control. A, C, D, R, S, V, WT, and LZ indicate G12A-, G12C-, G12D-, G12R-, G12S-, G12V-, wildtype-, and LacZ transfected cells, respectively. The asterisk indicates $* * * P$ value $<0.001$

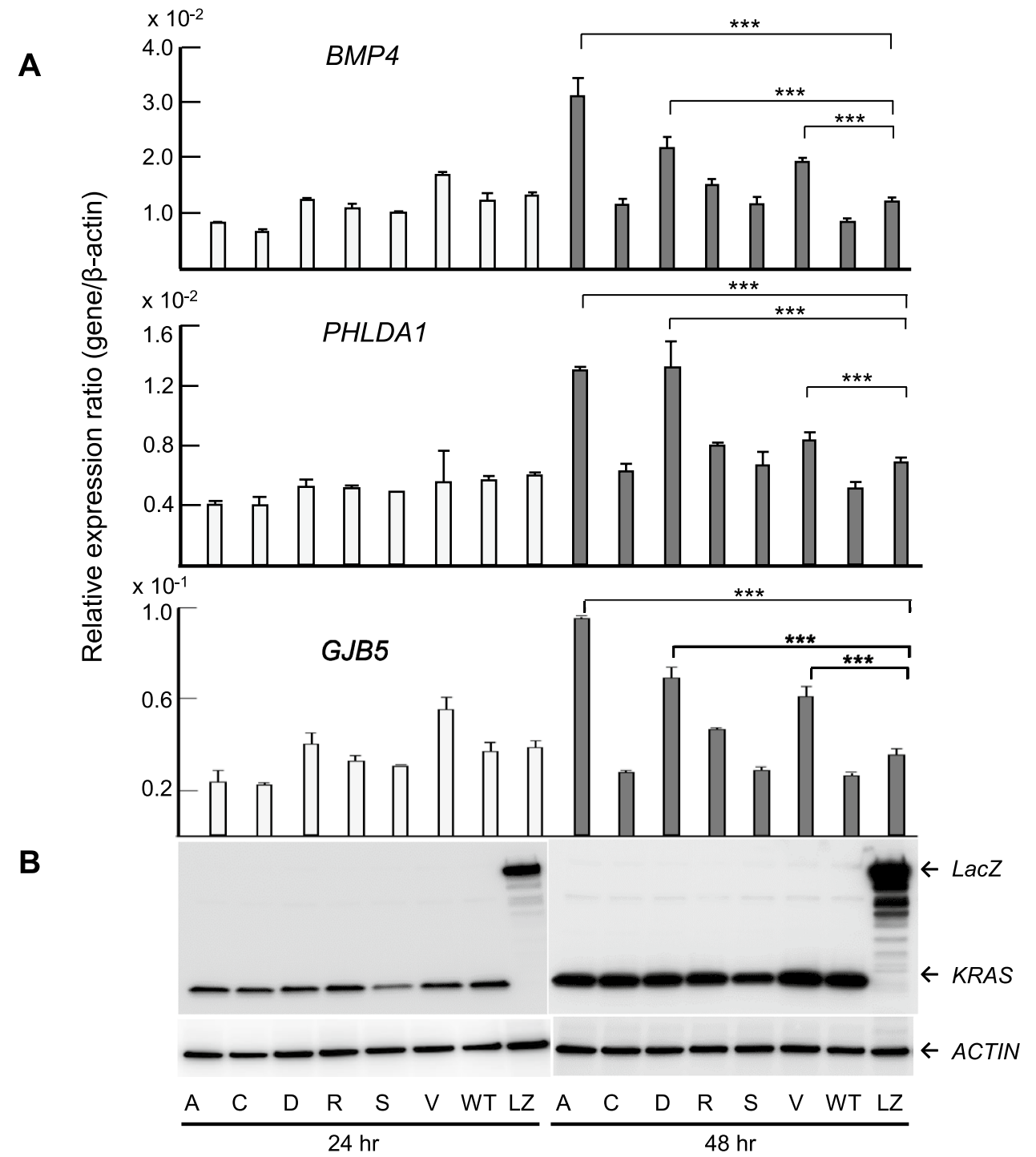

$\mathrm{G} 12 \mathrm{~V}$, which is predicted to be a moderate RAF activator [36], is associated with both RAF kinase and PI3K in NIH3T3 cells [37]. Therefore, it is suggested that the signals of KRAS mutation have different biological properties depending on mutation type and differentially affect the final gene expression process in the signal transduction cascade. The genes identified in our study may be involved in CRC development ant progression by directly or indirectly regulating the expression of these genes, depending on the type of KRAS mutation. To clarify the detailed mechanisms of KRAS mutation-induced differential gene expression patterns, further investigations are necessary. Furthermore, in CRC, G12A, G12D, and G12V mutations account for $85 \%$ of all KRAS G12 mutations. Therefore, it may also contribute to the acceleration of personalized medicine for CRC patients with these mutations. Our study has added these genes to the list of those that are possibly involved in colorectal carcinogenesis.
$B M P 4$ belongs to the TGF $\beta$ superfamily and has been reported to be involved in the regulation of various biological processes such as tissue organization of colonic epithelial cells, interaction between epithelial cells and stromal cells, epithelial-mesenchymal transition (EMT) induction, and metastasis [38, 39]. Additionally, BMP4 has been reported to promote colon cancer cell invasiveness and tumor formation [40]. Therefore, it is suggested that genes induced by the activation of BMP4-dependent signaling may be involved in the carcinogenesis and progression of CRC. In contrast, another study showed that BMP4 was involved in the suppression of colon cancer cell growth and that the activated $K R A S$ down-regulated BMP4 via the ERK pathway [41]. A possible explanation for this apparent controversy could be that these differential roles accounted to the differences in cell lines used among those studies. Aberrant activation of the $\mathrm{Wnt} / \beta$-catenin pathway enhances BMP4 signaling in colorectal cancer cells [42]. Therefore, although there was 


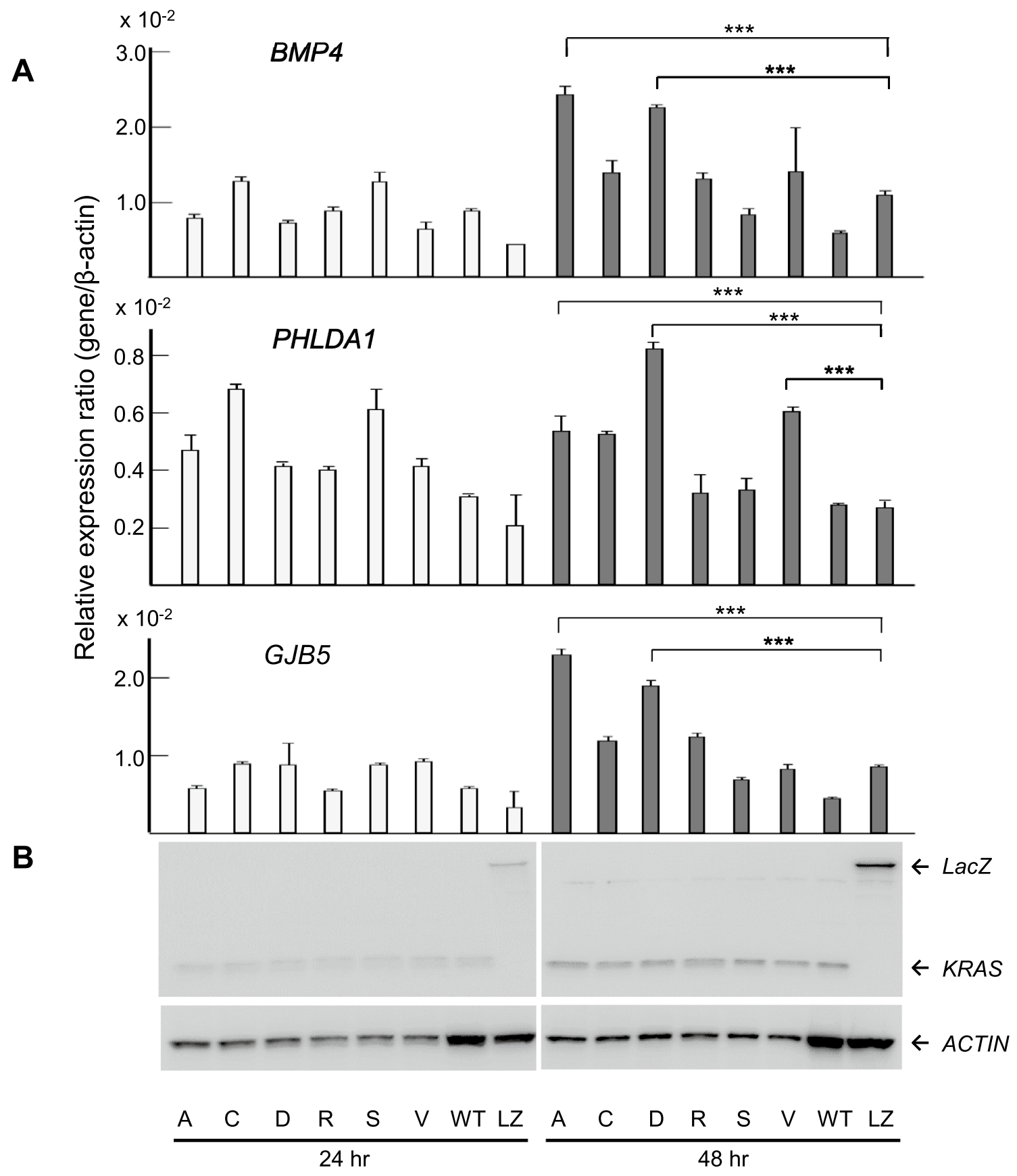

Fig. 5 Expression of BMP4, PHLDA1, and GJB5 are validated using qPCR in the KRAS G12 mutant transfected Caco- 2 cells: a Relative expression ratio is defined as the ratio between the expression level of a gene to that of the internal reference gene, $\beta$-actin. b KRAS protein

a possibility that $B M P 4$ expression was increased by inactivation of $A P C$ in CRC, no difference was observed in the frequency of $A P C$ mutation depending on the presence or absence of KRAS mutations in this study. PHLDAl may be a transcriptional activator that is induced by various external stimuli and acts as a mediator of apoptosis, proliferation, differentiation, and cell migration depending on the expression in the Caco-2 cells are analyzed using Western blot with V5 and $\beta$-actin antibodies. The assays are carried out the same as that show in Fig. 4. The asterisk indicates $* * * P$ value $<0.001$

cell type and physiological context [43]. It has also been suggested that PHLDAl is a putative epithelial stem cell marker in the small and large human intestine and contributes to the migration and proliferation of colon cancer cells [44], and it may contribute to the understanding of the oncogenic mechanism of colorectal carcinogenesis. However, the mechanistic basis for KRAS activation and/or PHLDAl in 
A

BMP4
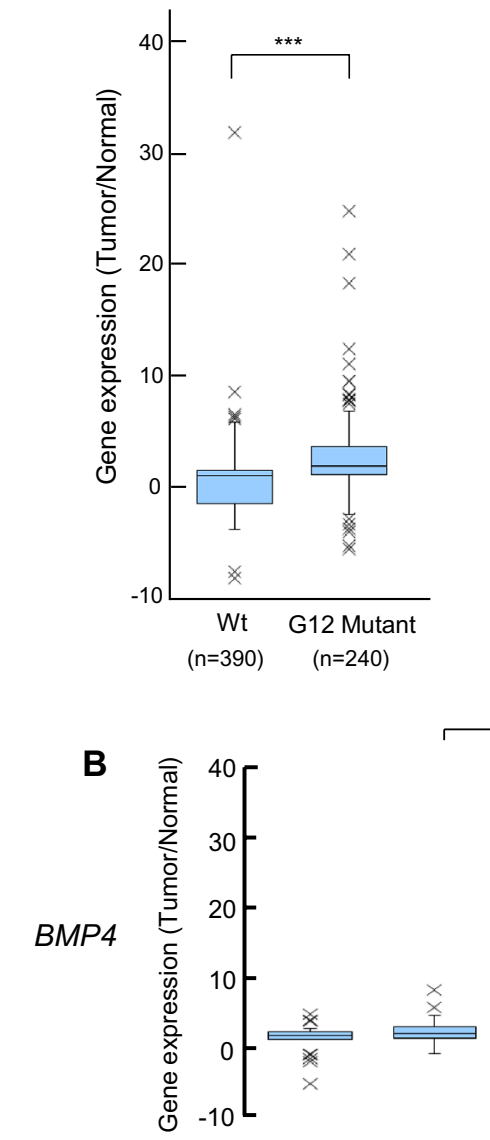

PHLDA1
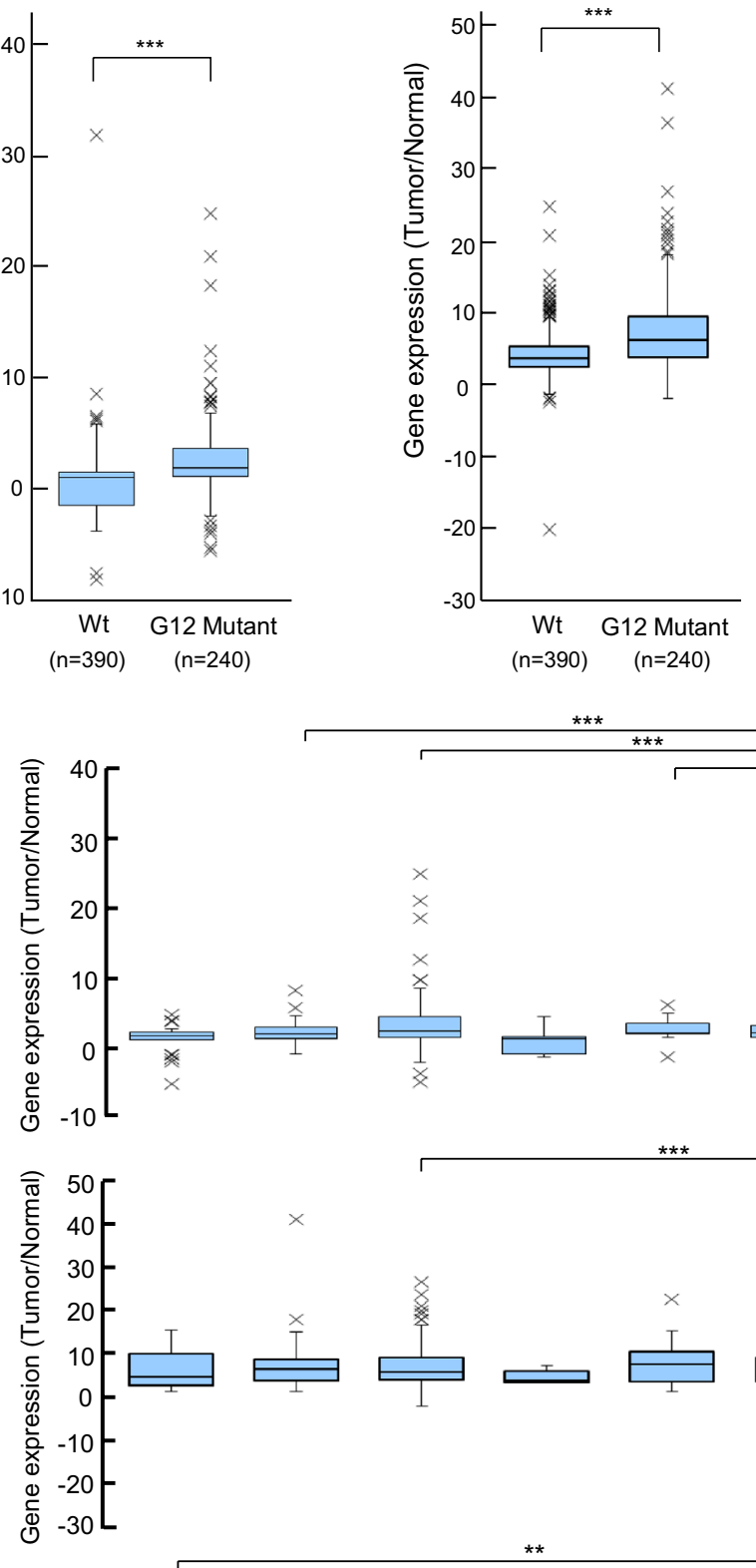

PHLDA1

GJB5

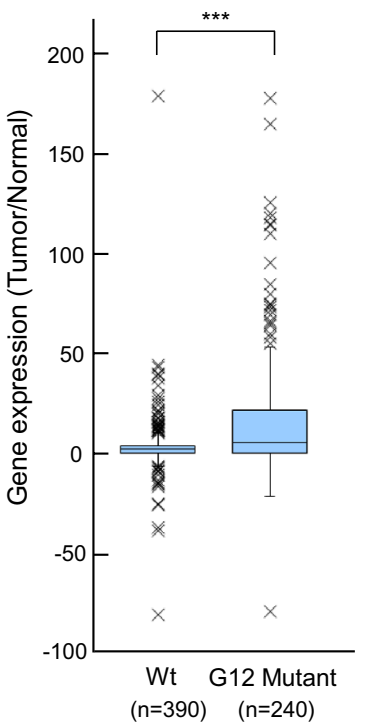


4Fig. 6 BMP4, PHLDA1, and GJB5 expression levels in CRC with $K R A S$ G12 mutant and wild-type (a) or KRAS-G12A, -G12C, -G12D, -G12R, -G12S, -G12V mutants, and wild-type (b). The expression level $(\log 2)$ was normalized for each gene. $* * *$ indicates $P<0.001$; ** indicates $P<0.01$

CRC has not been fully elucidated, and it should be determined by further investigation. GJB5 is a member of the connexin family that regulates cell adhesion, proteolysis, and motility. Connexins have been shown to function as tumor suppressors in cancer $[45,46]$ and have been reported to regulate EMT, tumor cell differentiation, and angiogenesis [47]. Among different members of the connexin family, GJB5 has not been described in association with colorectal cancer or RAS signaling, and the role of GJB5 in colorectal carcinogenesis remains largely unknown. Therefore, it is prudent to exclude this gene as a drug-targetable candidate in $\mathrm{CRC}$ at this time.

In recent years, various combinations of existing molecular targets [48], synthetic lethal partners [49], and immune checkpoint inhibitors [50] for RAS-activating signals have been extensively developed, and tumor suppressive effects have been shown in animal models. The genes identified in this study may be effective targets when used in combination with existing inhibitors of the MAPK pathway, such as MEK or BRAF inhibitors. The role of the genes identified in this study in the carcinogenesis and progression of CRC with KRAS G12 mutations may be a modulation of the cancer phenotype, the nature of which should be elucidated in future studies. We believe that our study will lead to further
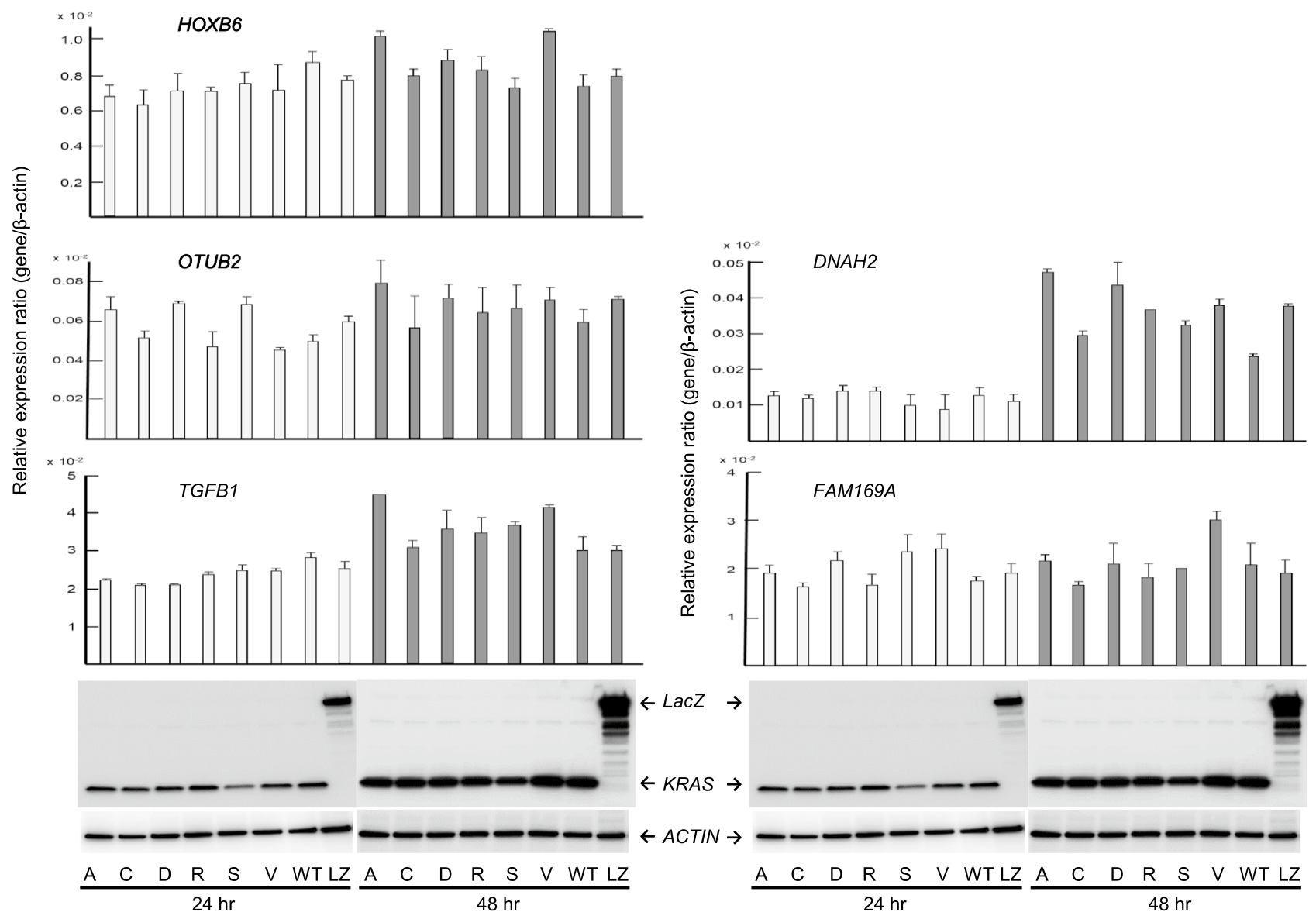

Fig. 7 Five genes, excluding $B M P 4, P H L D A 1$, and GJB5 shown in Table 2 are validated using qPCR in the KRAS G12 mutant transfected cell. All genes show a difference in up-regulation but this difference is not significant compared to KRAS wild-type or LacZ

transfected cells. SLC28A3, TMEM211, and C2orf70 genes shown in Table 2 are not detected by qPCR. The assays are carried out in triplicate, and means \pm standard deviations are plotted 

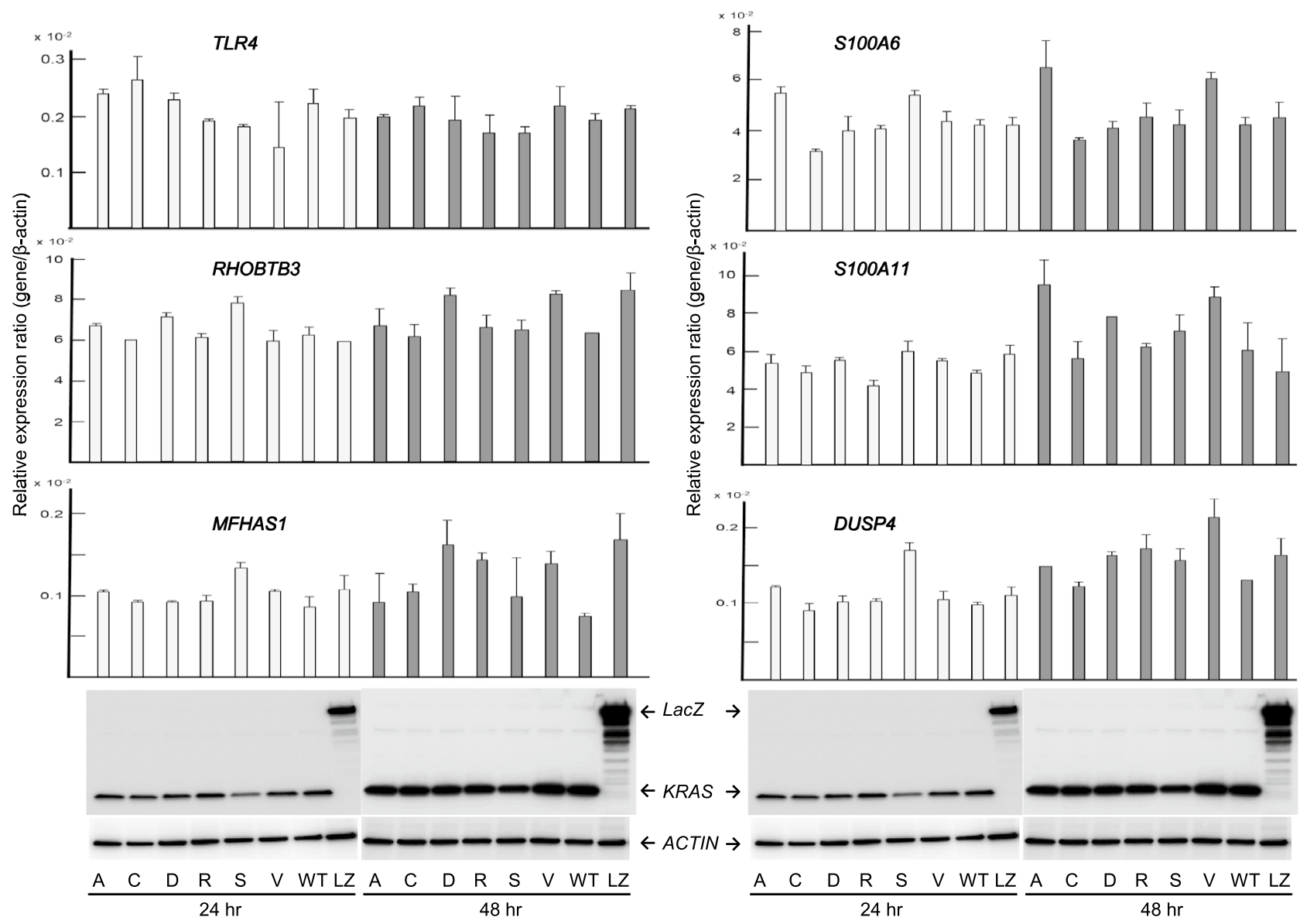

Fig. 8 Validation of TLR4, RHOBTB3, MFHAS1, S100A6, S100A11, and DUSP4 genes that had a BH-adjusted $P$ value less than $1.00 \mathrm{E}-$ 10 between KRAS G12 mutated and wild-type CRC, which have been implicated in the oncogenic function. All genes were not validated by

functional characterization of genes in the context of KRASbased individualized therapy.

Supplementary Information The online version contains supplementary material available at https://doi.org/10.1007/s11010-021-04172-8.

Acknowledgements This work was supported by a KAKENHI Grantin-Aid for Scientific Research (18K07957) from the Japan Society for the Promotion of Science (JSPS).

\section{Declarations}

Conflict of interest The authors have no conflicts of interest to declare.

Open Access This article is licensed under a Creative Commons Attribution 4.0 International License, which permits use, sharing, adaptation, distribution and reproduction in any medium or format, as long as you give appropriate credit to the original author(s) and the source, provide a link to the Creative Commons licence, and indicate if changes were made. The images or other third party material in this article are included in the article's Creative Commons licence, unless indicated

qPCR. The Western blot analysis of transfected cell is the same as that show in Fig. 6. The assays are carried out in triplicate and means \pm standard deviation were plotted

otherwise in a credit line to the material. If material is not included in the article's Creative Commons licence and your intended use is not permitted by statutory regulation or exceeds the permitted use, you will need to obtain permission directly from the copyright holder. To view a copy of this licence, visit http://creativecommons.org/licenses/by/4.0/.

\section{References}

1. Hashiguchi Y, Muro K, Saito Y, Ito Y, Ajioka Y, Hamaguchi T, Hasegawa K, Hotta K, Ishida H, Ishiguro M, Ishihara S, Kanemitsu Y, Kinugasa Y, Murofushi K, Nakajima T, Oka S, Tanaka T, Taniguchi H, Tsuji A, Uehara K, Ueno H, Yamanaka T, Yamazaki K, Yoshida M, Yoshino T, Itabashi M, Sakamaki K, Sano K, Shimada Y, Tanaka S, Uetake H, Yamaguchi S, Yamaguchi N, Kobayashi H, Matsuda K, Kotake K, Sugihara K (2020) Japanese society for cancer of the colon and rectum (JSCCR) guidelines 2019 for the treatment of colorectal cancer. Int J Clin Oncol 25:1-42. https://doi.org/10.1007/s10147-019-01485-Z

2. Oki E, Ando K, Nakanishi R, Sugiyama M, Nakashima Y, Kubo N, Kudou K, Saeki H, Nozoe T, Emi Y, Maehara Y (2018) Recent 
advances in treatment for colorectal liver metastasis. Ann Gastroenteral Surg 2:167-175. https://doi.org/10.1002/ags3.12071

3. Sepulveda AR, Hamilton SR, Allegra CJ, Grody W, CushmanVokoun AM, Funkhouser WK, Kopetz SE, Lieu C, Lindor NM, Minsky BD, Monzon FA, Sargent DJ, Singh VM, Willis J, Clark J, Colasacco C, Rumble RB, Temple-Smolkin R, Ventura CB, Nowak JA (2017) Molecular biomarkers for the evaluation of colorectal cancer: guideline from the American society for clinical pathology, college of American pathologists, association for molecular pathology, and the American society of clinical oncology. J Clin Oncol 35:1453-1486. https://doi.org/10.1200/JCO. 2016.71.9807

4. Roock WD, Claes B, Bernasconi D, Schutter JD, Biesmans B, Fountzilas G, Kalogeras KT, Kotoula V, Papamichael D, Laurent-Puig P, Penault-Llorca F, Rougier P, Vincenzi B, Santini D, Tonini G, Cappuzzo F, Frattini M, Molinari F, Saletti P, Dosso SD, Martini M, Bardelli A, Siena S, Sartore-Bianchi A, Tabernero J, Macarulla T, Fiore FD, Gangloff AO, Ciardiello F, Pfeiffer P, Qvortrup C, Hansen TP, Cutsem EV, Piessevaux H, Lambrechts D, Delorenzi M, Tejpar S (2010) Effects of KRAS, BRAF, NRAS, and PIK3CA mutations on the efficacy of cetuximab plus chemotherapy in chemotherapy-refractory metastatic colorectal cancer: a retrospective consortium analysis. Lancet Oncol 11:753-762. https://doi.org/10.1016/S1470-2045(10)70130-3

5. Ledford $H$ (2015) The ras renaissance. Nature 520:278-280. https://doi.org/10.1038/520278a

6. Simanshu DK, Nissley DV, McCormick F (2017) RAS proteins and their regulators in human disease. Cell 170:17-33. https://doi. org/10.1016/j.cell.2017.06.009

7. Haigis KM, Kendall KR, Wang Y, Cheung A, Haigis MC, Glickman JN, Niwa-Kawakita M, Sweet-Cordero A, Sebolt-Leopold J, Shannon KM, Settleman J, Giovannini M, Jacks T (2008) Differential effects of oncogenic K-Ras and N-Ras on proliferation, differentiation and tumor progression in the colon. Nat Genet 40:600-608. https://doi.org/10.1038/ng.115

8. Cox AD, Fesik SW, Kimmelman AC, Luo J, Der CJ (2014) Drugging the undruggable RAS: mission possible? Nat Rev 13:828851. https://doi.org/10.1038/nrd4389

9. Yokoyama N, Kim Y-J, Hirabayashi Y, Tabe Y, Takamori K, Ogawa H, Iwabuchi K (2019) Kras promotes myeloid differentiation through $\mathrm{Wnt} / \beta$-catenin signaling. FASEB BioAdv 1:435449. https://doi.org/10.1096/fba.2019-00004

10. Zhang Z, Wang Y, Vikis HG, Johnson L, Liu G, Li J, Anderson MW, Sills RC, Hong HL, Devereux TR, Jacks T, Guan K-L, You M (2001) Wildtype Kras2 can inhibit lung carcinogenesis in mice. Nat Genet 29:25-33. https://doi.org/10.1038/ng721

11. James RM, Arends MJ, Plowman SJ, Brooks DG, Miles CG, West JD, Patek CE (2003) K-ras proto-oncogene exhibits tumor suppressor activity as its absence promotes tumorigenesis in murine teratomas. Mol Cancer Res 1:820-825

12. Spandidos DA, Sourvinos G, Tsatsanis C, Zafiropoulos A (2002) Normal ras genes: their onco-suppressor and pro-apoptotic functions (review). Int J Oncol 21:237-241. https://doi.org/10.3892/ ijo.21.2.237

13. Singh A, Sowjanya AP, Ramakrishna G (2005) The wild-type Ras: road ahead. FASEB J 19:161-169. https://doi.org/10.1096/ fj.04-258hyp

14. Ihle NT, Byers LA, Kim ES, Saintigny P, Lee JJ, Blumenschein GR, Tsao A, Liu S, Larsen JE, Wang J, Diao L, Coombes KR, Chen L, Zhang S, Abdelmelek MF, Tang X, Papadimitrakopoulou V, Minna JD, Lippman SM, Hong WK, Herbst RS, Wistuba II, Heymach JV, Powis G (2012) Effect of KRAS oncogene substitutions on protein behavior: implications for signaling and clinical outcome. J Natl Cancer Inst 104:228-239. https://doi. org/10.1093/jnci/djr523
15. Yuan TL, Amzallag A, Bagni R, Yi M, Afghani S, Burgan W, Fer N, Strathern LA, Powell K, Smith B, Waters AM, Drubin D, Thomson T, Liao R, Greninger P, Stein GT, Murchie E, Cortez E, Egan RK, Procter L, Bess M, Cheng KT, Lee C-S, Lee LC, Fellmann C, Stephens R, Luo J, Lowe SW, Benes CH, McCormick F (2018) Differential effector engagement by oncogenic KRAS. Cell Rep 22:1889-1902. https://doi.org/10.1016/j.celrep.2018.01.051

16. Margetis N, Kouloukoussa M, Pavlou K, Vrakas S, MariolisSapsakos T (2017) K-ras mutations as the earliest driving force in a subset of colorectal carcinomas. Vivo 31(4):527-542

17. Vogelstein B, Fearon ER, Hamilton SR, Kern SE, Preisinger AC, Leppert M, Smits AMM, Bos JL (1988) Genetic alterations during colorectal-tumor development. N Engl J Med 319:525532. https://doi.org/10.1056/NEJM198809013190901

18. Bahrami A, Hassanian SM, ShahidSales S, Farjami Z, Hasanzadeh M, Anvari K, Aledavood A, Maftouh M, Ferns GA, Khazaei M, Avan A (2018) Targeting RAS signaling pathway as a potential therapeutic target in the treatment of colorectal cancer. J Cell Physiol 233:2058-2066. https://doi.org/10.1002/jcp.25890

19. Wilson CY, Tolias P (2016) Recent advances in cancer drug discovery targeting RAS. Drug Discov Today 21:1915-1919. https:// doi.org/10.1016/j.drudis.2016.08.002

20. Brand TM, Wheeler DL (2012) KRAS mutant colorectal tumors Small GTPase 3:34-39. https://doi.org/10.1038/onc.2010.430

21. Janne PA, van den Heuvel MM, Barlesi F, Cobo M, Mazieres J, Crino L, Orlov S, Blackhall F, Wolf J, Garrido P, Poltoratskiy A, Mariani G, Ghiorghiu D, Kilgour E, Smith P, Kohlmann A, Carlile DJ, Lawrence D, Bowen K, Vansteenkiste J (2017) Selumetinib plus docetaxel compared with docetaxel alone and progressionfree survival in patients with $K R A S$-mutant advanced non-small cell lung cancer, the select-1 randomized clinical trial. JAMA 317:1844-1853. https://doi.org/10.1001/jama.2017.3438

22. Brauswetter D, Gurbi B, Varga A, Varkondi E, Schwab R, Banhegyi G, Fabian O, Keri G, Valyi-Nagy I, Petak I (2017) Molecular subtype specific efficacy of MEK inhibitors in pancreatic cancers. PLoS ONE 12:e0185687. https://doi.org/10.1371/journal.pone. 0185687

23. Kitajima S, Asahina H, Chen T, Guo S, Quiceno LG, Cavanaugh JD, Merlino AA, Tange S, Terai H, Kim JW, Wang X, Zhou S, Xu M, Wang S, Zhu Z, Thai TC, Takahashi C, Wang Y, Neve R, Stinson S, Tamayo P, Watanabe H, Kirschmeier PT, Wong K-K, Barbie DA (2018) Overcoming resistance to dual innate immune and MEK inhibition downstream of KRAS. Cancer Cell 34:439_ 452. https://doi.org/10.1016/j.ccell.2018.08.009

24. Ostrem JM, Peters U, Sos ML, Wells JA, Shokat KM (2013) K-Ras (G12C) inhibitors allosterically control GTP affinity and effector interactions. Nature 503:548-551. https://doi.org/10. 1038/nature 12796

25. Janes MR, Zhang J, Li L-S, Hansen R, Peters U, Guo X, Chen Y, Babbar A, Firdaus SJ, Darjania L, Feng J, Chen JH, Li S, Li S, Long YO, Thach C, Liu Y, Zarieh A, Ely T, Kucharski JM, Kessler LV, Wu T, Yu K, Wang Y, Yao Y, Deng X, Zarrinkar PP, Brehmer D, Dhanak D, Lorenzi MV, Hu-Lowe D, Patricelli MP, Ren P, Liu Y (2018) Targeting KRAS mutant cancers with a covalent G12C-specific inhibitor. Cell 172:578-589. https://doi. org/10.1016/j.cell.2018.01.006

26. McCormick F (2020) Sticking it to KRAS: covalent inhibitors enter the clinic. Cancer Cell 37:3-4. https://doi.org/10.1016/j. ccell.2019.12.009

27. Malumbres M, Barbacid M (2003) RAS oncogens: the first 30 years. Nat Rev 3:7-13. https://doi.org/10.1038/nrc1097

28. Jones RP, Sutton PA, Evans JP, Clifford R, McAvoy A, Lewis J, Rousseau A, Mountford R, McWhirter D, Malik HZ (2017) Specific mutations in KRAS codon 12 are associated with worse overall survival in patients with advanced and recurrent colorectal 
cancer. Br J Cancer 116:923-929. https://doi.org/10.1038/bjc. 2017.37

29. Nagashima T, Yamaguchi K, Urakami K, Shimoda Y, Ohnami S, Ohshima K, Tanabe T, Naruoka A, Kamada F, Serizawa M, Hatakeyama K, Matsumura K, Ohnami S, Maruyama K, Mochizuki T, Kusuhara M, Shiomi A, Ohde Y, Terashima M, Uesaka K, Onitsuka T, Nishimura S, Hirashima Y, Hayashi N, Kiyohara Y, Tsubosa Y, Katagiri H, Niwakawa M, Takahashi K, Kashiwagi H, Nakagawa M, Ishida Y, Sugino T, Takahashi M, Akiyama Y (2020) Japanese version of The cancer genome atlas, JCGA, established using fresh frozen tumors obtained from 5143 cancer patients. Cancer Sci 111:687-699. https://doi.org/10.1111/cas. 14290

30. Ohshima K, Hatakeyama K, Nagashima T, Watanabe Y, Kanto K, Doi Y, Ide T, Shimoda Y, Tanabe T, Ohnami Su, Ohnami S, Serizawa M, Maruyama K, Akiyama Y, Urakami K, Kusuhara M, Mochizuki T, Yamaguchi K (2017) Integrated analysis of gene expression and copy number identified potential cancer driver genes with amplification-dependent overexpression in 1454 solid tumors. Sci Rep 7:641. https://doi.org/10.1038/ s41598-017-00219-3

31. Ohnami S, Ohshima K, Nagashima T, Urakami K, Shimoda Y, Saito J, Naruoka A, Hatakeyama K, Mochizuki T, Serizawa M, Ohnami Su, Kusuhara M, Yamaguchi K (2017) Comprehensive characterization of genes associated with the TP53 signal transduction pathway in various tumors. Mol Cell Biochem 431:75-85. https://doi.org/10.1007/s11010-017-2977-1

32. Hatakeyama K, Nagashima T, Ohshima K, Ohnami Su, Ohnami S, Shimoda Y, Serizawa M, Maruyama K, Naruoka A, Akiyama Y, Urakami K, Kusuhara M, Mochizuki T, Yamaguchi K (2019) Mutational burden and signatures in 4000 Japanese cancers provide insights into tumorigenesis and response to therapy. Cancer Sci 110:2620-2628. https://doi.org/10.1111/cas.14087

33. Ministry of Health, Labour and Welfare. Japanese ethical guidelines for human genome/gene analysis research. 2017. https:// www.mhlw.go.jp/stf/seisakunitsuite/bunya/hokabunya/kenkyujigy ou/i-kenkyu/index.html. Accessed 17 Sept 2019

34. Ohnami S, Sato Y, Yoshimura K, Ohnami Su, Sakamoto H, Aoki K, Ueno H, Ikeda M, Morizane C, Shimada K, Sakamoto Y, Esaki M, Saito I, Hirose H, Saito D, Sugimura H, Kosuge T, Okusaka T, Yoshida T (2008) His595Tyr polymorphism in the methionine synthase reductase $(M T R R)$ gene is associated with pancreatic cancer risk. Gastroenterology 135:477-488. https://doi.org/10. 1053/j.gastro.2008.04.016

35. Serebriiskii IG, Connelly C, Frampton G, Newberg J, Cooke M, Miller V, Ali S, Ross JS, Handorf E, Arora S, Lieu C, Golemis EA, Meyer JE (2019) Comprehensive characterization of RAS mutations in colon and rectal cancers in old and young patients. Nat Commun 10:3722. https://doi.org/10.1038/s41467-019-11530-0

36. Hunter JC, Manandhar A, Carrasco MA, Gurbani D, Gondi S, Westover KD (2015) Biochemical and structural analysis of common cancer-associated KRAS mutations. Mol Cancer Res 13:1325-1335. https://doi.org/10.1158/1541-7786.MCR-15-0203

37. Céspendes MV, Sancho FJ, Guerrero S, Parreño M, Casanova I, Pavón MA, Marcuello E, Trias M, Cascante M, Capellà G, Mangues R (2006) K-ras Asp12 mutant neither interacts with Raf, nor signals through Erk and is less tumorigenic than K-ras Val12. Carcinogenesis 27:2190-2200. https://doi.org/10.1093/carcin/ bg 1063

38. Ma J, Zeng S, Zhang Y, Deng G, Qu Y, Guo C, Yin L, Han Y, Cai C, Li Y, Wang G, Bonkovsky HL, Shen H (2017) BMP4 promotes oxaliplatin resistance by an induction of epithelial-mesenchymal transition via MEK1/ERK/ELK1 signaling in hepatocellular carcinoma. Cancer Lett 411:117-129. https://doi.org/10.1016/j.canlet. 2017.09.041
39. Theriault BL, Shepherd TG, Mujoomdar ML, Nachtigal MW (2007) BMP4 induces EMT and Rho GTPase activation in human ovarian cancer cells. Carcinogenesis 28:1153-1162. https://doi. org/10.1093/carcin/bgm015

40. Yokoyama Y, Watanabe T, Tamura Y, Hashizume Y, Miyazono K, Ehata S (2017) Autocrine BMP-4 signaling is a therapeutic target in colorectal cancer. Cancer Res 77:4026-4038. https://doi.org/ 10.1158/0008-5472.CAN-17-0112

41. Duerr E-M, Mizukami Y, Moriichi K, Gala M, Jo W-S, Kikuchi H, Xavier RJ, Chung DC (2012) Oncogenic KRAS regulates BMP4 expression in colon cancer cell lines. Am J Physiol Gastrointest Liver Physiol 302:G1223-G1230. https://doi.org/10.1152/ajpgi. 00047.2011

42. Kim J-S, Crooks H, Dracheva T, Nishanian TG, Singh B, Jen $\mathrm{J}$, Waldman T (2002) Oncogenic $\beta$-catenin is required for bone morphogenetic protein 4 expression in human cancer cells. Cancer Res 62:2744-2748

43. Nagai MA (2016) Pleckstrin homology-like domain, family A, member 1 (PHLDA1) and cancer (Review). Biomed Rep 4:275281. https://doi.org/10.3892/br.2016.580

44. Sakthianandeswaren A, Christie M, D'Andreti C, Tsui C, Jorissen RN, Li S, Fleming NI, Gibbs P, Lipton L, Malaterre J, Ramsay RG, Phesse TJ, Ernst M, Jeffery RE, Poulsom R, Leedham SJ, Segditsas S, Tomlinson IPM, Bernhard OK, Simpson RJ, Walker F, Faux MC, Church N, Catimel B, Flanagan DJ, Vincan E, Sieber OM (2011) PHLDA1 expression marks the putative epithelial stem cells and contributes to intestinal tumorigenesis. Cancer Res 71:3709-3719. https://doi.org/10.1158/0008-5472.CAN-10-2342

45. Shettar A, Damineni S, Mukherjee G, Kondaiah P (2018) Gap junction $\beta-2$ expression is negatively associated with the estrogen receptor status in breast cancer tissues and is a regulator of breast tumorigenesis. Oncol Rep 40:3645-3653. https://doi.org/10.3892/ or.2018.6764

46. Zhang D, Chen C, Li Y, Fu X, Xie Y, Li Y, Huang Y (2012) Cx31.1 acts as a tumor suppressor in non-small cell lung cancer (NSCLC) cell lines through inhibition of cell proliferation and metastasis. J Cell Mol Med 16:1047-1059. https://doi.org/10. 1111/j.1582-4934.2011.01389.x

47. Aasen T, Mesnil M, Naus CC, Lampe PD, Laird DW (2016) Gap junctions and cancer: communicating for 50 years. Nat Rev Cancer 16:775-788. https://doi.org/10.1038/nrc.2016.105

48. Manchado E, Weissmueller S, Morris JP IV, Chen C-C, Wullenkord R, Lujambio A, Stanchina E, Poirier JT, Gainor JF, Corcoran RB, Engelman JA, Rudin CM, Rosen N, Lowe SW (2016) A combinatorial strategy for treating KRAS mutant lung cancer. Nature 534:647-651. https://doi.org/10.1038/nature18600

49. Downward J (2015) RAS synthetic lethal screens revisited: still seeking the elusive prize? Clin Cancer Res 21:1802-1809. https:// doi.org/10.1158/1078-0432.CCR-14-2180

50. Dietlein F, Kalb B, Jokic M, Noll EM, Strong A, Tharun L, Ozretic L, Kunstlinger H, Kambartel K, Randerath WJ, Jungst C, Schmitt A, Torgovnick A, Richters A, Rauh D, Siedek F, Persigehl T, Mauch C, Bartkova J, Bradley A, Sprick MR, Trumpp A, Rad R, Saur D, Bartek J, Wolf J, Buttner R, Thomas RK, Reinhardt HC (2015) A synergistic interaction between Chk1- and MK2 inhibitors in KRAS-mutant cancer. Cell 162:146-159. https://doi. org/10.1016/j.cell.2015.05.053

Publisher's Note Springer Nature remains neutral with regard to jurisdictional claims in published maps and institutional affiliations. 